Reprod. Nutr. Dévelop., 1982, 22 (6), 923-930.

\title{
Influence of photoperiod on the time of parturition in the rat. III. Comparison of different daily light lengths with changes in light timing or light pulse given during darkness.
}

\author{
M. J. BOSC, Agnès NICOLLE
}

Station de Physiologie de la Reproduction, I.N.R.A. Nouzilly, 37380 Monnaie, France

\begin{abstract}
Summary. The time of birth has been determined in rats isolated and divided into different groups according to the light regime applied throughout pregnancy (day 1 : beginning of pregnancy). The majority of deliveries in all groups occurred during two well-defined periods, the first on the afternoon of day 22 of gestation and the second on day 23 at the end of darkness or the beginning of the light phase. On day 22 of gestation, 47.1, 58.7 and $76.0 \mathrm{p} .100$ of the births occurred in groups daily receiving $14 \mathrm{~h}$ (control group C), $12 \mathrm{~h}$ (group I) and $8 \mathrm{~h}$ (group S), respectively, of light; the photoperiod finished at the same time of day in all these groups. Birth rates similar to those of group $C$ were observed on days 22 and 23 as follows : (1) in two S groups (S19 and S21) submitted to $8 \mathrm{~h}$ of light daily with an additional 1-h flash ending 19 or $21 \mathrm{~h}$ after dawn and (2) in group $\mathrm{SI}$ submitted to $8 \mathrm{~h}$ of light with $4 \mathrm{~h}$ suddenly added at mid-gestation at the beginning of the photoperiod. When $4 \mathrm{~h}$ of light were suddenly added to this 8 -h regime at mid-gestation, but at the end of the photoperiod, the majority of births $(90.7$ p. 100) occurred on day 22 of gestation. These results, indicating that birth time in the rat depends on photoperiodic timing, confirm the view that in this species there exists a photosensitive phase susceptible to photic stimulation.
\end{abstract}

\section{Introduction.}

Birth time in the rat depends on the daily light length (Mitchell and Yochim, 1970 ; Bosc and Nicolle, 1980 a). In order to explain this photoperiodic response, the existence of a photosensitive phase according to the concept of Bünning has been suggested (Bünning, 1960 ; Pittendrigh and Minis, 1964 ; Elliott, 1976). In this concept, this photo-dependent biological process relies on the coincidence of light with the responsive part of an endogenous photosensitive rhythm related to this process. In a previous study (Bosc and Nicolle, $1980 \mathrm{~b}$ ), we used night interrupted photoschedules to reveal this light-sensitive phase. In our conditions, one hour of light given a few hours before the beginning of the main photoperiod modified birth distribution; this effect was interpreted as resulting from the stimulation of a light-sensitive phase. However, it is possible to interpret this effect differently, ie as depending on the location of efficient flashes. If the ani- 
mals perveived the flash as real dawn, the modification of birth distribution would be due to subjective lengthening of the daily illumination. The present experiment was carried out to investigate this question again. Different daily light lengths were compared to changes in light timing or to efficient light pulses given during darkness. The time of birth was determined to study the effects of the light regime.

\section{Material and methods.}

Animals. - We used rats originating from strain 03 of our colony. Their management has been described previously (Bosc and Nicolle, 1980 a). Briefly, they were kept in temperature $\left(21 \pm 1^{\circ} \mathrm{C}\right)$ and light-controlled rooms. The standard light regime was $14 \mathrm{~h}$ of light and $10 \mathrm{~h}$ of darkness (14L: 10D) with lightsof from 6 a.m. to $8 \mathrm{p} . \mathrm{m}$. According to this light regime, ovulation is assumed to occur around 3 a.m. (Everett, 1964 ; McCormak and Sridaran, 1978) in all the experimental groups.

At 70 to 90 days of age, the females were caged with the males for 3 successive days. Mated animals were isolated on the day of mating (day 1 of pregnancy ; spermatozoa in the vaginal smear) in individual boxes and assigned to an experimental group. Two or three sessions per group were needed, and the females were allowed two or three pregnancies (Bosc and Nicolle, 1980 a).

Light regimes. - Seven groups were constituted according to the light regimes given on table 1 and schematically represented on figures 1 and 2 . Three groups received simple daily light treatment : group $S$ (short photoperiod : $8 \mathrm{~h}$ ), group I (intermediate photoperiod : $12 \mathrm{~h}$ ) and group $\mathrm{C}$ (control photoperiod : $14 \mathrm{~h}$ ). The end of the photoperiod (or dusk) in these three groups remained that of the standard light regime $(8 \mathrm{p.m}$.). Two groups of rats were submitted to the short light regime with an additional light pulse of $1 \mathrm{~h}$ ending 19 (group S19) or 21 (group S21) $h$ after the beginning of the main photoperiod (or conventional dawn). The light pulse was given throughout gestation in these groups since it had been previously shown (Bosc and Nicolle, 1980 b) that such pulses stimulated the light-sensitive phase. The rats in the last two groups were put under the short photoperiod (8L : 16D) of group S, but only during the first-half of pregnancy from day 1 until day 12 or 13 . At that stage of gestation, the daily photoperiod was suddenly increased from 8 to $12 \mathrm{~h}$ and remained that way until the end of pregnancy. In one of the two groups, an additional $4 \mathrm{~h}$ of light were given in the morning, thus changing the time of dawn (group SI) : in the other group, these $4 \mathrm{~h}$ were added on in the evening, changing the time of dusk (group In SI).

Observations. - Observations were made as described previously (Bosc and Nicolle, $1980 \mathrm{a}$ ), the onset of expulsion being the time of delivery. The animals were monitored every $2 \mathrm{~h}$ on days 22 and 23 of pregnancy, and the beginning of pup expulsion was plotted at $2-h$ intervals.

Birth rates on days 22 and 23 of gestation were compared according to the chi-square analysis of Pearson (Vessereau, 1960) and birth distribution curves 
according to the non-parametric test of Kolmogoroff-Smirnoff (Siegel, 1956). In each litter, the total number of rats born and the number of those born alive were determined ; live pups were weighed 2 to $6 \mathrm{~h}$ after the end of parturition. Litter size, stillbirth rate and mean birth weight were then compared (Snedecor and Cochran 1957 ; Siegel, 1956).

\section{Results.}

In all the experimental groups, the majority of births occurred during two well-defined periods, the first on the afternoon of day 22 of gestation and the second on the morning of day 23 ; few births were observed during the dark interval between these two periods.

According to this pattern, the birth rates on these two days were representative of the light treatments presented on table 1. Under the control light regime (group C), 47.1 p. 100 of the births occurred on day 22 and 52.9 p. 100 on day 23. In group $S I$ and in groups $S 19$ and $S 21$ which were pooled $(P>0.05)$, the births were also divided equally between day 22 and day 23 as in group $C$ $(\mathrm{P}>0.05)$. In groups $\mathrm{S}$ and In SI, 76 and 90.7 p. 100 of the births, respectively, were observed on day 22 of gestation ; these groups differed from groups $\mathrm{C}, \mathrm{SI}$, $\mathrm{S} 19$ and S21 ( $\mathrm{P}<0.01$ ). $2 \times 2$ comparisons of the distribution curves using the Kolmogoroff-Smirnoff test were in agreement with the comparisons of the birth rates on days 22 and 23 of gestation.

TABLE 1

Birth rate on days 22 and 23 of gestation in rats submitted to different light regimes throughout gestation

\begin{tabular}{|c|c|c|c|c|}
\hline \multirow{2}{*}{ Group } & Light/day (h) & \multicolumn{3}{|c|}{ Parturition (\%) } \\
\hline & $\begin{array}{c}\text { first-half second-half } \\
\text { of gestation }\end{array}$ & day 22 & day 23 & Total \\
\hline C & (6 a.m. -8 p.m.) & $\begin{array}{l}24 \\
(47.1)\end{array}$ & $\begin{array}{l}27 \\
(52.9)\end{array}$ & $\begin{array}{l}51 \\
(100) \\
\end{array}$ \\
\hline 1 & (8 a.m. -8 p.m.) & $\begin{array}{c}27 \\
(58.7)\end{array}$ & $\begin{array}{c}19 \\
(41.3) \\
\end{array}$ & $\begin{array}{c}46 \\
(100) \\
\end{array}$ \\
\hline $\mathbf{S}$ & (12 a.m. -8 p.m.) & $\begin{array}{l}38 \\
(76.0)\end{array}$ & $\begin{array}{c}12 \\
(24.0)\end{array}$ & $\begin{array}{l}50 \\
(100) \\
\end{array}$ \\
\hline SI & $\begin{array}{l}8 \\
\text { (12 a.m. }-8 \text { p.m.) }\end{array}$ & $\begin{array}{l}23 \\
(47.9)\end{array}$ & $\begin{array}{l}25 \\
(52.1)\end{array}$ & $\begin{array}{l}48 \\
(100)\end{array}$ \\
\hline InSI & $\stackrel{8}{8} \quad{ }^{12}$ a.m. -8 p.m.) $\quad(12$ a.m. -12 p.m. $)$ & $\begin{array}{l}39 \\
(90.7)\end{array}$ & $\begin{array}{l}4 \\
(9.3) \\
\end{array}$ & $\begin{array}{c}43 \\
(100) \\
\end{array}$ \\
\hline $\mathrm{S} 19$ & $\begin{array}{c}8+1 \\
\text { (12 a.m. }-8 \text { p.m. ; } 6 \text { a.m. }-7 \text { a.m.) }\end{array}$ & \multirow{2}{*}{$\begin{array}{l}31 \\
(46.3)\end{array}$} & \multirow{2}{*}{$\begin{array}{l}36 \\
(53.7)\end{array}$} & \multirow{2}{*}{$\begin{array}{l}67 \\
(100)\end{array}$} \\
\hline S21 & $\begin{array}{c}8+1 \\
\text { (12 a.m. - } 8 \text { p.m. ; } 8 \text { a.m. - } 9 \text { a.m.) }\end{array}$ & & & \\
\hline
\end{tabular}

$\mathrm{P}<0.01$ for inSI vs $\mathrm{C}, \mathrm{I}, \mathrm{SI}, \mathrm{S} 19+\mathrm{S} 21$ and for $\mathrm{S}$ vs $\mathrm{C}, \mathrm{SI}, \mathrm{S} 19+\mathrm{S} 21$. 
Birth frequencies on days 22 and 23, computed only on births observed on each of these days, are shown on figures 1 and 2 . On day 22,83 to 87 p. 100 of the births in all groups were clustered over periods lasting 6 to $8 \mathrm{~h}$ (fig. 1). The

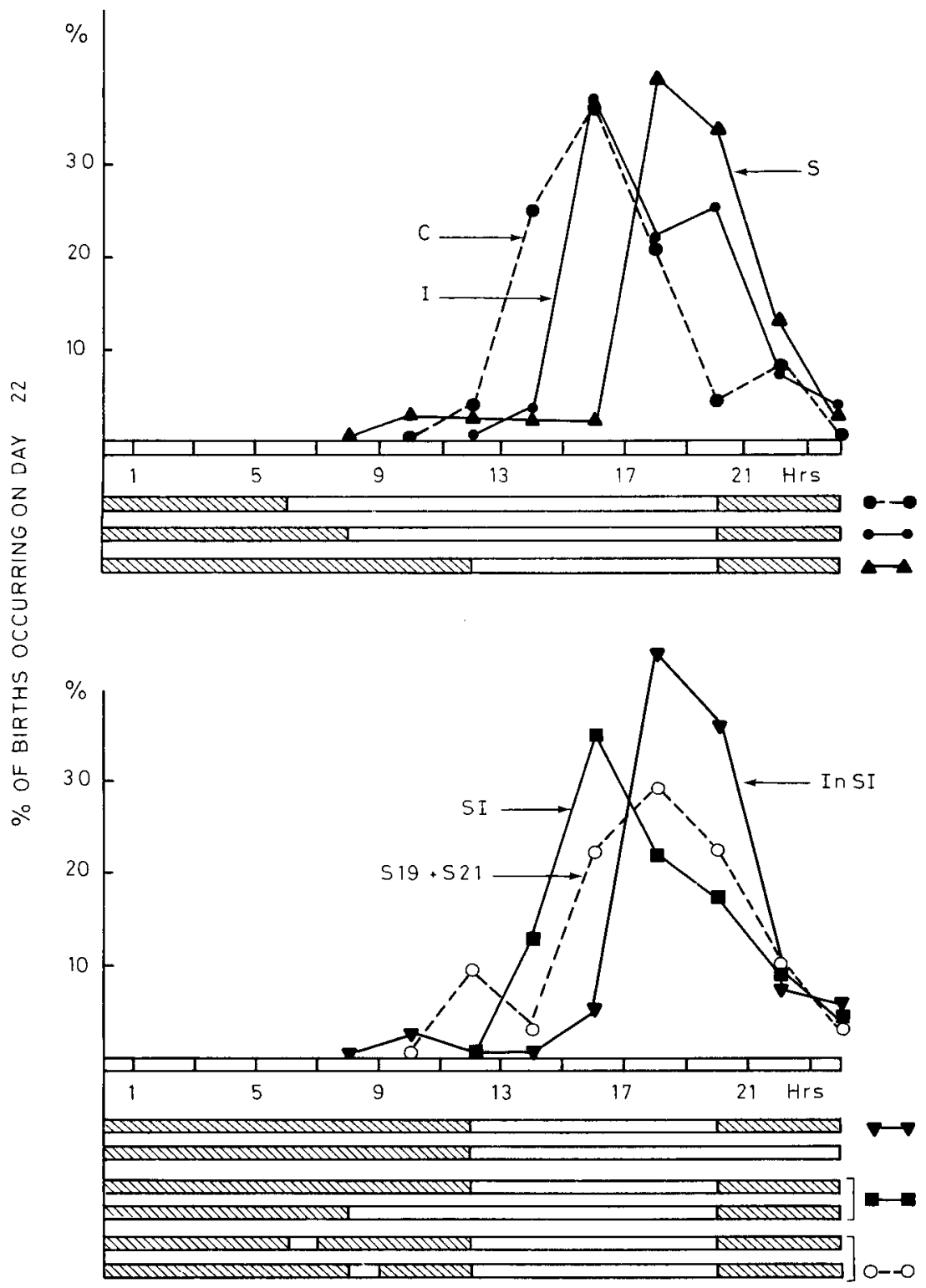

FIG. 1. - Birth distribution on day 22 of gestation in rats submitted to different light regimes throughout pregnancy. Frequencies were computed only from births observed on this day. Upper part: Groups $C(14 \mathrm{~L}: 10 \mathrm{D} ; \mathrm{n}=24), \mathrm{I}(12 \mathrm{~L}: 12 \mathrm{D} ; \mathrm{n}=27)$ and $\mathrm{S}(8 \mathrm{~L}: 16 \mathrm{D} ; \mathrm{n}=38)$. Lower part: Groups SI $(n=23)$ and In SI $(12 \mathrm{~L}: 12 \mathrm{D}$ from mid-gestation; $n=39)$ and groups $\mathrm{S} 19+\mathrm{S} 21$ (8L: $15 \mathrm{D}+1 \mathrm{~h}$ of light ending 19 or $21 \mathrm{~h}$ after dawn; $\mathrm{n}=31$ ). 
interval between dawn and birth time averaged $10 \mathrm{~h} 06( \pm 2 \mathrm{~h} \mathrm{32})$ in groups $\mathrm{C}, \mathrm{I}$ and SI (P > 0.05), whereas it was $7 \mathrm{~h} 12( \pm 2 \mathrm{~h} \mathrm{38})$ in groups $S$, In SI and $S 19+S 21(P>0.05)$. Thus, these periods were spread over the same time in groups $\mathrm{S}$ and In $\mathrm{SI}$ and in groups I and $\mathrm{SI}$ which had the same dawn during the second-half of gestation. A shift was observed between groups $C, I$ and $S$ which had the same dusk but not the same dawn. On day 23 of gestation, the births extended over the same period in the three groups which had a significant number of deliveries on that day (fig. 2).

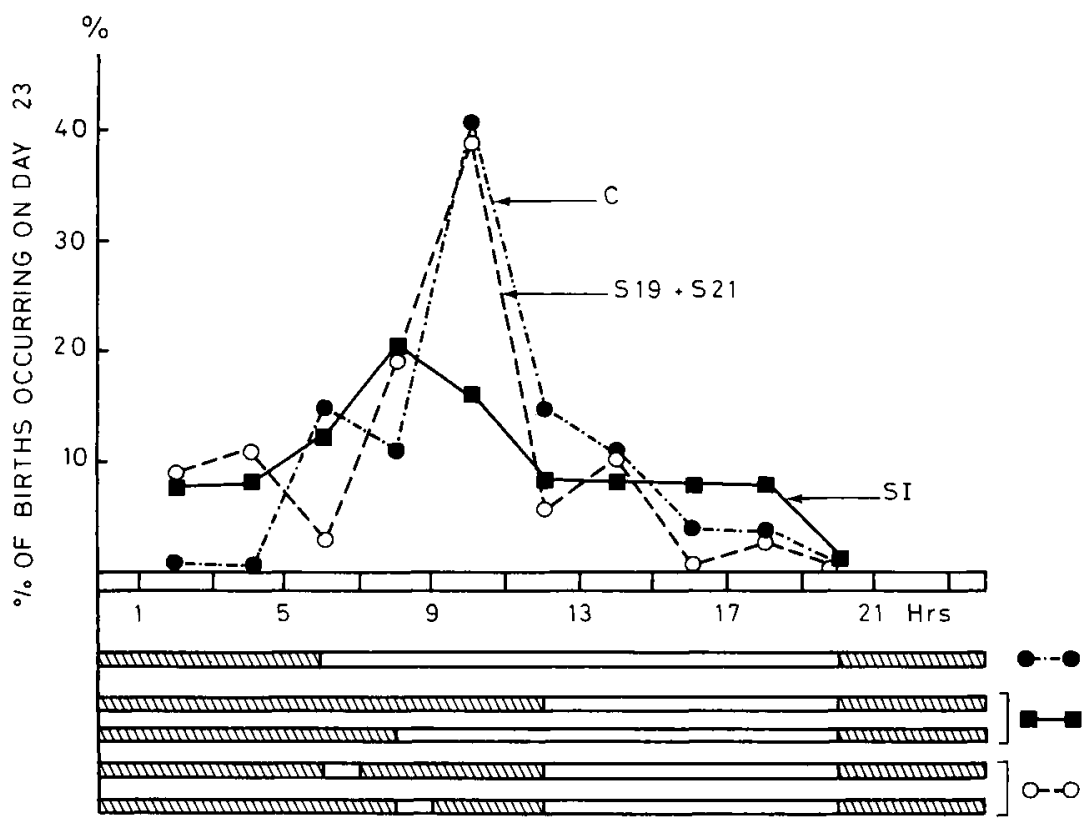

FIG. 2. - Birth distribution on day 23 of gestation in rats submitted to different light regimes throughout pregnancy. Frequencies were computed only from births observed on this day. Group $C(14 \mathrm{~L}: 10 \mathrm{D} ; \mathrm{n}=27)$, group $\mathrm{SI}(12 \mathrm{~L}: 12 \mathrm{D}$ from mid-gestation; $\mathrm{n}=25)$, groups $\mathrm{S} 19+\mathrm{S} 21(8 \mathrm{~L}: 15 \mathrm{D}+1 \mathrm{~h}$ of light ending 19 or $21 \mathrm{~h}$ after dawn ; $\mathrm{n}=36$ ). Groups $\mathrm{I}, \mathrm{S}$ and $\mathrm{In}$ $\mathrm{SI}$ are not represented because of the low number of births observed.

Litter size and the number of animals with stillbirths were similar among the experimental groups $(P>0.05)$ but stillbirth rates were different $(P<0.01)$. This difference was apparently unrelated to the light regime, but the frequency of stillbirth increased with increased length of gestation (concordance coefficient of Kendall, $W=0.50 ; P<0.05)$ when the last two days of gestation were divided into four main classes. This trend was the reverse of that observed for litter size where there were no differences between groups. However, the mean birth weight of live pups increased regularly from day 22 to day 23 of pregnancy in all groups (no difference between groups). 


\section{Discussion.}

In this experiment, the inter-group differences in birth rate on days 22 and 23 of gestation could not be attributed to the variation in litter size or stillbirth rate which is usually related to the length of gestation (Reynolds, 1965 ; Bosc and Nicolle, 1980 a) or the length of labour (Bosc and Nicolle, 1979).

This study, showing that the time of birth in rat is influenced by photoperiodic timing, supports the view that in this species there exists a phase which may be stimulated by light. As in preceding works, the delivery rates on the last two days of gestation were inversely related to the daily photoperiod in groups $C$ (14L : 10D), I (12L : 12D) and S (8L : 16D). However, the foregoing hypothesis cannot be applied to groups $\mathrm{SI}$ and In SI which received the same amount of light throughout gestation but with different timing from mid-pregnancy (table 1). In group In SI when $4 \mathrm{~h}$ of light were added at the end of an 8-h photoperiod, most births occurred on day 22 of gestation; in contrast, when $4 \mathrm{~h}$ of light were added at the beginning of the same photoperiod (group SI), a significant number of deliveries occurred on day 23 . In the latter group, the births were distributed as in groups S19 and S21 which received a flash ending 19 or $21 \mathrm{~h}$ after conventional dawn.

These results, as those obtained previously with night interrupted photoschedules (Bosc and Nicolle, 1980 b), suggest that the light-sensitive phase in the pregnant rat is situated a few hours before dawn under the 8 -h photoperiods used in these experiments.

In this study, the delivery rates on days 22 and 23 of gestation in groups SI, S19 and S21 were not different from that of the control group C, also suggesting that the light-sensitive phase was normally stimulated under such a standard light regime and that it was located around the time of dawn.

As seen in previous studies (Lincoln and Porter, 1976 ; Bosc and Nicolle, 1980 a), births occurred during well-defined periods over the last two days of gestation, depending on the light regime. In the present experiment, these periods were particularly marked on day 22 of gestation (fig. 1), occurring on that day after a mean time-lapse characteristic of the timing of dawn and of the daily photoperiod. The situation was less convincing on day 23 of gestation (fig. 2).

As the time of birth in the rat depends on the alternation of light and dark periods (Bosc, 1981), it can be assumed that the initiation of labour is affected by endocrine events related to this alternation. As shown in this study and in others (Lincoln and Porter, 1976 ; Bosc, 1981), the apparent difference between the timing of births on the last two days of gestation suggests that the birth mechanism is affected in two different ways on these last two days.

This study supports the hypothesis of the existence of a light-sensitive phase which affects the birth time in rat. However, from the birth distribution, it would be interesting to determine the influence of this phase on each of the last 
days of gestation. This experiment also shows that birth time depends on the timing of the photoperiod rather than on its duration. This apparent discrepancy with earlier works calls for a re-evaluation of the effects of daily illumination.

Reçu en janvier 1982.

Accepté en juin 1982.

Acknow/edgements. - Thanks are due to Mr. Beguey and his team for animal care and to colleagues who participated in monitoring the animals.

Résumé. Influence de la photopériode sur le moment de la naissance chez la rate. III. Effets comparés de la durée quotidienne d'éclairement, de la modification de la position de la photopériode et d'un flash lumineux appliqué au cours de l'obscurité.

Le moment de la naissance a été déterminé sur des rates isolées et réparties en des lots différents selon le régime lumineux appliqué dès la saillie $\left(J_{1}\right.$ : début de la gestation). Dans tous les lots, la majorité des naissances a été observée au cours de deux périodes déterminées, la $1^{\text {re }}$ |'après-midi du $22^{\mathrm{e}}$ jour de la gestation, la $2^{\mathrm{e}}$ le $23^{\mathrm{e}}$ jour, en fin de nuit ou au début de la phase claire. Ainsi, au cours du $22^{\mathrm{e}}$ jour de la gestation, 47,$5 ; 58,7$ et 76,0 p. 100 des mise-bas ont été respectivement observées dans des lots recevant par jour : $14 \mathrm{~h}$ (lot $\mathrm{C}$ ou lot Témoin), $12 \mathrm{~h}$ (lot 1 ) ou $8 \mathrm{~h}$ (lot $S$ ) de lumière, la phase claire se terminant à la même heure pour chacun d'eux. Des taux de mise-bas identiques à ceux du lot $C$, au cours de ces 2 jours, ont été constatés dans les cas suivants : 1) Dans deux lots (Lots S19-S21) soumis comme le lot $\mathrm{S}$ à $8 \mathrm{~h}$ de lumière par jour avec en supplément un flash lumineux de $1 \mathrm{~h}$ finissant 19 et $21 \mathrm{~h}$ après l'aube. 2) Dans un lot (Lot SI) ayant reçu comme le lot $\mathrm{S}, 8 \mathrm{~h}$ de lumière auxquelles ont été ajoutées brutalement à mi-gestation $4 \mathrm{~h}$ de lumière en début de phase claire. En revanche, 90,7 p. 100 des mise-bas ont été observées le $22^{\circ}$ jour lorsque, au régime du lot $\mathrm{S}, 4 \mathrm{~h}$ de lumière ont été données brutalement à mi-gestation en fin de phase claire (Lot $\ln \mathrm{SI}$ ).

Ces résultats indiquent que le moment de la naissance chez la rate est influencé par la position de la photopériode au cours du nycthémère; ils supportent l'hypothèse qu'il existe dans cette espèce une phase photosensible susceptible d'une stimulation lumineuse.

\section{Références}

BOER K., LINCOLN D. W., SWAAB D. F., 1975. Effects of electrical stimulation of neurohypophysis on labour in the rat. J. Endocr., 65, 153-176.

BOSC M. J., 1981. Effects of photoperiod on the time of birth in the rat. Coll. I.N.R.A., $n^{\circ} 6,33-50$.

BOSC M. J., NICOLLE A., 1979. Effect of stress on the course of labor and parturition time in normal or adrenalectomized rats. Ann. Biol. anim. Bioch. Biophys., 19, 31-44.

BOSC M. J., NICOLLE A., 1980a. Influence of photoperiod on the time of parturition in the rat. I. Effect of the length of the daily illumination in normal or adrenalectomized animals. Reprod. Nutr. Dévelop., 20, 735-745. 
BOSC M. J., NICOLLE A., 1980b. Influence of photoperiod on the time of parturition in the rat. II. Demonstration of a photoinducible phase and determination of some of its characteristics. Reprod. Nutr. Dévelop., 20, 939-948.

BÜNNING E., 1980. Circadien rhythms and time measurement in photoperiodism. In Biological clocks. Cold Spring Harb. Symp. Quant. Biol., 25, 249-257.

ELLIOTT J. A., 1976. Circadian rhythms and photoperiodic time measurement in mammals. Fed. Proceed., 35, 2339-2346.

EVERETT J. W., 1964. Central neural control of reproductive functions of the adenohypophysis. Physiol. Rev., 44, 373.

LINCOLN D. W., PORTER D. G., 1976. Timing of the photoperiod and the hour of birth in rats. Nature Lond., 260, 780-781.

McCORMAK C. E., SRIDARAN R., 1978. Timing of ovulation in rats during exposure to continuous light: evidence for a circadian rhythm of luteinizing hormone secretion. J. Endocr., 76, 135-144.

MITCHELL J. A., YOCHIM J. M., 1970. Influence of environmental lighting on duration of pregnancy in the rat. Endocrinology, 87, 472-480.

PITTENDRIGH C. S., MINIS D. M., 1964. The entrainment of circadian oscillations by light and their role as photoperiodic clocks. Amer. Natur., 98, 261-294.

REYNOLDS S. R. M., 1965. The physiology of the uterus. Hafner Publ. Co. New York, p. 619.

SIEGEL S., 1956. Non-parametric statistics for the behavioral sciences. Int. Student Ed. McGraw-Hill Bock Co. Me. Kogakusha Co Ltd.

SNEDECOR G. W., COCHARAN W. G., 1957. Statistical methods. 6th. Ed., The lowa State Univ. Press., Ames, U.S.A.

VESSEREAU A., 1960. In Recherche et experimentation en agriculture, Tome $2^{\mathrm{e}}$. Méthodes statistiques en biologie et en agronomie. Ed. J.B. Baillères et Fils, Paris, p. 539. 